\title{
ISLAM, GLOBALIZATION, AND POVERTY ALLEVIATION
}

\author{
Dwi Sulastyawati*
}

\begin{abstract}
Abstrak: Islam, Globalisasi, dan Pengentasan Kemiskinan. Globalisasi adalah keadaan dan situasi yang menglobal, baik secara ekonomi, politik, dan sosial. Semua negara yang menganut sistem perekonomian terbuka telah berperan serta dalam sistem globalisasi. Saat ini dunia berada di bawah pengaruh super power dunia. Misalnya adalah penggunaan dolar sebagai mata uang resmi untuk transaksi internasional sehingga dolar mendominasi dalam transaksi international. Akibatnya, nilai utang negara-negara berkembang mengalami kenaikan disebabkan kenaikan harga dolar. Kenaikan nilai utang negara-negara berkembang menyebabkan pemerintah mengurangi subsidi bagi masyarakat, sehingga kesulitan ekonomi makin dirasakan rakyat kecil. Hal ini berakibat kemiskinan sulit dihilangkan. Artikel ini menganalisis perspektif Islam dan pelbagai pemikiran mengenai dampak globalisasi terhadap penghapusan tingkat kemiskinan.
\end{abstract}

Kata Kunci: Islam, globalisasi, kemiskinan, ekonomi

Abstract: Islam, Globalization, and Poverty Alleviation. Globalization is global as well condition and situation, neither economically, politically, and socially. All countries that embrace open economic system have participated in the system of globalization. Today the world is under the influence of super power world. For instance, using dollar as the official currency for international transactions, so that dollar dominates in international transactions. As a result, the value of the debt of developing countries has increased due to the rising price of dollar. The increment of the debt value in developing countries led the government reduces subsidies for the community. Thus economic hardship perceived more and more for poor people. This resulted that poverty is hard to be alleviated. This article analyzes the various Islamic perspective and thoughts on the impact of globalization on poverty alleviation.

Kata Kunci: islam, globalization, poverty, economy

Recieved: 7th March 2013, revised: 13rd June 2013, accepted: 20th June 2013.

* Sekolah Tinggi Agama Islam Negeri (STAIN) Curup, Bengkulu. Jl. Dr. Ak. Gani No. 1, Rejang Lebong, Bengkulu. E-mail: dwi_Sulastyawati@gmail.com 


\section{Introduction}

Globalization is a process of increasing the connectivity and interdependence of the worlds markets and businesses. The process has speeded up dramatically in the last two decades as technological advances make it easier for people to travel. Two major recent driving forces are advances in telecommunications infrastructure and the rise of the internet in general.

It also means integration between people around the world, in term of circulation of goods, labors, and capital. We can not avoid globalization, but in global economy, should be there global prosperity, where state, market, and civil society live in harmony. Many books written about globalization, mostly discuss its meaning and impacts. It's impact debatable, whether it gives positive or it gives negative impacts to the world. The definition of globalization in this paper regards its meaning in economics concept. This paper criticizes globalization in regard of developing country where the global poverty raises year by year. Major problem are poor countries can not compete fairly to the world, and there is political power of rich countries over poor countries.

\section{Globalization}

Globalization in an economics term is inreasing interdependence among nations and among people around the world in form of trade, investment, and finance which has the same characteristic with internationalitation. It describes "flows of capital, commodities among people across national borders. Key actors are transnational corporation; key feature are electronic communications and rapid transfer of technology". ${ }^{1}$ In the same tone that "Globalization today involves the increasing interdependence of national economies, financial markets, trade, corporations, production, Contribution and consumer marketing. ${ }^{2}$

Transnational corporation is any corporation that is registered and operates in more than one country at a time. Usually also known as multinational corporation. Foreign corporation has various motives for establishing a corporate existence in other countries. Another motive is to escape the protectionist policies of an import product, reduce cost of production as price of raw material and labor are cheaper in developing countries. This practice disturb traditional economies, and generally this corporation has the abolity to monopolize the market, and mainly compel a political and economic agenda on a country.

\footnotetext{
${ }^{1}$ Jean Gelman Taylor, Global Indonesia, (USA: Routledge, 2012), p. 1.

${ }^{2}$ Hazel Handerson, Quoted by Ikram Azam, The New Political Economy Paradigm, (Islamabad: Pakistan Futuristics Foundation \& Institute, 2003), p. 104.
} 
The advance in electronic communication and rapid transfer of technology help businesses grows faster. It also help in rapid growtg of economies of countries. The world has offer human being all easy access and process for goods and services by the help of technology. It create larger market, more job, more import product with cheaper price but it is beneifited large importir, small local businesses lose out. Easier acces for news and information with the help of technology, this is a fruit of globalization.

Other than that increasing in integration of national economies, capital flows, information and labor migration globalization also includes trend of "the declining power of nation state, in inverse relation to the rise of transnational corporation, financial corporations, financial markets and the arbitrations of the World Trade Organization (WTO)". ${ }^{3}$

Declining power of nations state, as they should accept the conditions and rules of super power countries for cutting subsidies ect. Globalization is not a single cause that made declining power of nations state but it help to do so. Developing countries should agree with an agreement of free trade even their people are not ready yet. They should folloe World Trade Organization decisions.

WTO is international body that help promote free trade by drawing up the rules of international trade. And the rules carries the interest of rich countries. WTO campaign free trade. Free trade is a main characteristic of globalization itself. And characteristics of free trade are no barriers in international trade such tarrifs and quotas. One critics over WTO principle is that WTO very welcoming to large corporations, in this case it does not help the claims of free, open, and democratic economy.

Since the beginning of free trade by WTO (World Trade Organization) the globalization is good in its genial idealism, but "trade agreement are not structures tocreate a level playing field, but rather simply creates rules that favor these powerful countries and their well-organized producer interest". ${ }^{4}$ But, in its development, the impact of globalization does not equally distribute. There are a group of people who are really enjoying the impact and leave others marginalized. As the world does not equal itself, some are developed and some are developing. Some countries are ready to face the free trade, while some others are not ready. In this unequal situation, the impact of globalization does not equal

${ }^{3}$ Gloria Davies \& Chris Nyland (Editor), Asian Region: Impacts and Consequences, (UK: Edward Elgar Publishing Limited, 2004), p. 18.

${ }^{4}$ Sumner J. La Croix and Peter A Petri, New Challenges to the Global Trading System, in Challenges to the Global Trading System: Adjustment to Globalization in the Asia-Pacific Region, (New York: Routledge, 2007), p. 1. 
either. Developing countries mostly are not ready in facing globalization as liberalization. The people of developing countries cannot compete fairly with people of developed countries in capital and capability. That is why a government as decision maker should take wise decision about his country.

Three distinct strands in the process of globalization: increase freedom in the movement of goods, increased foreign direct investment, and increased foreign direct investment in financial markets. ${ }^{5}$

Transnational corporation is form of foreing direct investment. Multinational or transnational corporation eventually is mastering the market. With better quality product, brand, and marketing. In the capital market, foreing investor also has big influence in the market.

Besides freedom in movement of capital and goods, globalization made the world like in one village or global village. With the ease of technology borders between countries are no longer clear. With no barriers for trading and transacting in international scope, the world described as one village or global village. A global village created less barriers in economics activities among countries. And it help multinational corporation to establish their corporation easily. "Globalization may be seen as the world's space narrowing and the intensification of awareness that the world is a whole.... ${ }^{6}$ With less barrier in flow of goods and capitals, flow of labor made the world borderless.

There are many concepts and meanings of globalization it self. In term of freedom, space, economic, sosial, and politics. Here are some other meanings. According to Jan Art: ${ }^{7}$ First, globalization in terms of internationalization. It describes cross border relation betwen countries. It is a process of increasing involvement of enterprises in international market. Here interaction of people across nation in globalization in term of internationalization. Second, globalization as liberalization. Liberalization is easiness of goverment restriction in economic policy, and some time referred as deregulation. Third, conception has equated globalization with universalization. In this usage, global means worlwide and globalization. It is a process of spreading various objects and experinces to people at all corners of the earth. Fourth, definition has equated globalization with westernization. It is a process whereby societies come under or adopt western culture in term of technology, law, politics, economics, ect. It has been a per-

${ }^{5}$ William Oriscoll \& Julie Clarck (editor), Globalization and the Poor: Exploitation or Equalizer?, (USA: International debate Education Assosiation, 2003), p.16.

${ }^{6}$ Bernhard Limbong, Stop Making Money, (Jakarta: Margareta Pustaka, 2012), p. 14.

${ }^{7}$ Jan Art Scholte, Globalization a Critical Introduction, New York: St. Martin's Press, Inc, 2000), P. 15-16. 
vassive and accelerating influence across the world in the last few centuries. Fifth, idea identifies globalization as detterritorialization. Which means reconfiguration geography.

Its meaning as liberalization is the appropriate one for this paper. Here globalization refers to a process of removing goverment restriction on import product, between countries in order to create borderless world economy. Anyway it has good value for upper income level or upper level businessman economy. It is just like "small local business will be wiped out by large multinational companies in form of imperialist capitalism" in the communist manifesto.

Another form of globalization is capitalization it is givin new market for capitalist, giving more domination for developed countries and its allied countries to sell their product worldwide. Some view globalization as a project of superpower nation to expand their power. In this viewpoint, globalization is capitalization in its best form. Where superpower countries state restrain world economy, and than little countries becoming over a barell, because could not compete in world economy fairly.

\section{Globalization and Currency Exchange}

Another cause of globalization is currency exchange. Most of country apply floating exchange rate. In floating exchange rate system the price of currency determined by the demand and supply of currency. Currently the price of rupiah penetrating up to Rp 10.000 over US dollar. As the demand for dollar is increasing because of the increasing in demand for import.

"Globalization...., and at the moment, has severly caused an alarming global currency war" ${ }^{8}$ Every body know, \$US dominated most of currency's trade, and everybody wonder, why should dollars... not gold or others. A coutry owner of dollar currency dominated a world market, most of people and countries of the world depend on this currency (\$US). Since the collapse of bretton wood system, which is breached by Unated State everyone should not trust this currency anymore. Nixon, a president of America who broke the "Bretton Wood Agreement to safe the economy of his country. Since that, \$ US currency could not and should not be trusted anymore. But many countries keep this to keep their economy, for selling their product to America, as America is the biggest demander of goods and services for some countries.

${ }^{8}$ Sri Edi Swasono, "Revitalsasi Ekonomi Rakyat dalam Pengembangan Ekonomi Nasional", Seminar on 28th April 2012, STAIN Curup (Bengkulu). 
Jhon Perkins in the final analysis wrote "The global empire depends to a large extent on the fact that the dollar acts as the standard world currency, and than the United State mind has the rights to print those dollars. Thus, we make loans to countries like Ecuador with the full knowledge that they will never repay them; in fact we do not want them to honor their debt, since the nonpayment is what gives us our laverage, our pond of flesh, under normal conditions, we would run the risk eventually decimating our own funds; after all, no creditor can afford too many defaulted loans. However, ours are not normal circumtances. The United States prints currency that is not backed by gold. Indeed, it is not backed by anything other than a generela world wide confidence in our economy and our ability to marshal the forces and resources of the empire we have created to support us, the ability to print currency gives us immense power. It means, among other things, that we can continue to make loans that will never be repaid. ${ }^{9}$

As long as we accept the dollar as standard currency, American economy will be survive, in case there is another currency will replace US dollar, American economy will be collapse. In terms of free trade for instance, where world trade barries such tarriffs on import goods, restrictive quotas are removed, unfair for economic condition. Since the end of World War II, it has been the stated policy of most First World countries to eliminate protectionism through free trade policies enforced by international treaties and organizations such as the World Trade Organization. "As for the charges of hypocrisy, and unfair trade that are passionately leveled today at this international institutions and also at the rich nations-in particular that they maintain protection for themselves while force others in to fee trade". ${ }^{10}$ Ironic, but this is what is going on this world today.

\section{Impacts of Globalization}

Globalization era in sense of free regulation/free trade began in mid of 1080s. Prepared and pioneered by leading countries in order to improve international people's welfare. Globalization just the new form of "imperialism", trough giving developing countries an "aid", and than dictate them in politic and economy, with an agreement that they able tosell some products like food grains and movies of their owns to aided states, which improve donor state's economy. There is no problem in making countries debt provider rich economically, but

${ }^{9}$ John Perkins, Confession of an Economic Hit Man, (San Fransisco: Koehler Publisher, 2004), p. 212.

${ }^{10}$ Jagdis Bhagwati, In defense of Globalization, (New York: Oxford University Press, 2004), p. 3. 
the biggest problem is when debtor countries lost its independency in economy. And this is the new color of imperialism. When developing countries lost their dignity and political power in economy. For example aero plane industry in Indonesia stopped under IMF pressure. Because they do not want Indonesia compete developed countries in technology. We knew politics and economics like two sides of coin cannot be separated. In facing financial crisis 1007-2000 in order to have an aid from IMF (International Monetary Fund) Indonesia must stop incentive given to manufacturing industry, especially strategic industry. BUMN (state owned enterprises) was not only mismanagement, but also deliberately destroyed by foreign powers.

IMF adjusts different wisdom between developed countries and developing countries. And applied "multiple standards" in influencing government policy. In this sense "globalization" becomes an instrument for the benefit of developed countries. In facts, globalization must become an organization for increasing world trade on the basis mutual benefit. This is clear proof of economics imperialism on Indonesia. We lose our independency in determining our policy. "IMF oblige individual states the world over to adopt political and economic programmes that result in deregulation of industry and banks, privatization of national assets, limited government, tax cuts for the wealthy and reduction of state subsidies". ${ }^{11}$

IMF is International Monetary Fund, an international financial institution organized in 1945, Its headquarters are in Washington, D.C., United States. The IMF plays three major roles in the global monetary system. The Fund surveys and monitors economic and financial developments, lends funds to countries with balance-of-payment difficulties, and provides technical assistance and training for countries requesting it.

On the above citation there are few point on the facts of globalization today, it affirms on the fact there is new form of imperialism in Indonesia. In the form of economic imperialism, one simple sample is the ban of manufacturing industry for not giving an aid to revive manufacturing industry as a condition for getting an aid from IMF.

Deregulation in industries and banks is conditions for participating in free trade that be appointed by an organization that support liberalization in economics. In this case foreign capital is able to influence the financial of a country. And so does it is in capital market.

\footnotetext{
${ }^{11}$ Jean Gelman Taylor, Global Indonesia, p. 2.
} 
Privatization of national asset, five formula applied by IMF as precondition in giving aid to Indonesia after hit by financial crisis 1997, privatized basic services, an independent cenreal bank, "flexible" work forces, low social spending, and total free trade. ${ }^{12}$

Tax cuts for the whealty which promote inequality, reduction of state subsidies. Reduction of fuel subsidies happens in last three years which is recommended by IMF. And the reduction in fuel subsisied really burden low income people. On the other side reformation for the infrastructure is not going well as a conpensation of energy subsidies reduction.

The result of today's global economy on the poor is low prices that benefit first-world consumers, and often put the poor at even greater risk. As transnational corporation try to increase profit by reducing costs as labor with low skill are paid with lower price. Laborers, mostly in developing countries work long hours but are still poor, hungry and subject to abuse. Again rich getting richer and poor getting poorer. Some critics argue that "Globalization entrenches Western wealth and power. Poor nation cannot compete without tariff protection. Free trade is not fair trade. Third world government that accept IMF rules violate their citizens' sense that the state has a duty to keep the price of rice and cooking oil low through subsidies. Globalization is comprehensively condemned from Cuba to Malaysia as the triumph of Western economies grown rich through slavery, conquest, underdevelopment and cultural annihilation of the third world". ${ }^{13}$

A government that accept IMF rules ignore the needs of poor citizen. And the policy of government bolster inequality of income among people. The real value of money is decreasing, while to get the money is not an easy thing.

The result of today's global economy, "Give rise to adverse social sideeffects such as greater income inequality, environmental degradation, violation of labor and human rights standard, and destruction of order long-established cultures by an all-an compassing global popular culture." ${ }^{14}$ It also said that

${ }^{12}$ Hendri Tanjung and Asad Zaman, "Between Free Trade and Protectionism", Published in The Jakarta Post, 3rd may 2010, http;//thejakartapost.com/news/2010/05/03/between-free-trade-andprotectionism.html

${ }^{13}$ Hendri Tanjung and Asad Zaman, "Between Free Trade and Protectionism".

${ }^{14}$ Sumner J. La Croix and Peter A Petri, New Challenges to the Global Trading System, in Challenges to the Global Trading System: Adjustment to Globalization in the Asia-Pacific Region, (New York: Routledge, 2007), p. 1. 
"Financial globalization determines the so-called structural inequalities; as they are create a new distribution among the different income group". ${ }^{15}$

Economic inequality described as the gap between rich and poor, income inequality, wealth disparity, or wealth and income differences is the difference between individuals or populations in the distribution of their assets, wealth, or income. The term typically refers to inequality among individuals and groups within a society. And financial globalization create 'structural inequalities'. This is so because the capital is controlled by the capitalis.

\section{Positive and Negative Impacts}

Globalization has both positive and negative value, Bernhard limbong mentions both impacts as bellow: ${ }^{16}$ A number of benefits gained from economic globalization are: (1)Iimproves the global production, with the help of transfer of technology the positive impact is increasing the global production. As technology is one of factor of production. Trough an increament and innovation in technology the volume of production is improve as well. (2) Increase the people's welfare in a country. (3) Widens the market for domestic products. (4) Make easier capital and technology gaining. (5) Prepares additional capital to establish economy. Increase the people's welfare, widens the market, are be valid only for powerful country and powerful businessman of a country.

Some disadvantages caused by economic globalization: First, slows down the growth of industrial sector (dependency to industries owned by multinational companies keeps increasing), and a small economy will have no control over the world prices.

Second, worsen payment balance (less developing export may impact badly against balance of payment), and the need of import also increasing. And again worsen the balance of payment.

Third, the financial sector will be more unstable, with deregulation in industrial and capital sector the economic climate of a country so risky. An economy potentially much more sensitive to international crises. Fourth, worsens the prospect of long term economic growth.

Because the financial sector unstable, it made economic climate of a country unstable as well, the impact in the long term, the prospect of economic worsens, the rate of poverty, the rate of unemployment, inflation are increasing,

15 Felice Roberto Pizzuti, Introduction Market and Institutions in Neo-Globalization, in Globalization, Institutions and Social Cohesion, edited by Maurizio Franzini \& Felice R Pizzuti, (Germany: Heidelberg, 2001), p.14-15.

${ }^{16}$ See, Berhand Limbong, Stop Making Money, p. 17-18. 
the ability of people to consume is decreasing, and then investments sector is also decreasing, which led to decreasing in economic growth.

\section{Impacts on Inequality and Poverty}

Other impacts of globalization are: ${ }^{17}$ First, the increased Marginalization of the poor: individuals, groups, classes, indigenous peoples, society's nations and whole countries, e.g., in Africa, and even Asia. Second, greater gaps between the rich and poor-within countries and between them. Third, the new dichotomy between the "Info-Rich" and "Info-Poor". Fourth, aggravation of world-wide poverty, as established by the annual UNDP Human Development Report, from year to Year. About 30\% natures' productive potential has been killed. All mention above, we can say that globalization create income disparities sharper and even more.

From above illustration, there are common opinions. One of it massive impact of financial crises as happened in some of Asian countries and Latin America is collapse of exchange rate value or decrease in purchasing power of domestic people and the price of import product becomes more expensive. Another impact studied by James Levinsohn, the very poor were in fact the most vulnerable and harmed. From the financial crises in Indonesia in 1997, the value of currency (Rupiah) deteriorated sharply against Dollar, the purchasing power of Rupiah goes down by $66,77 \%$. One of the lessons from Indonesian experience is that the impact of the crises on the poor are dynamic and the evidence shows that the crises led to disadvantageous health among infants and children in poorer households. The long term impact of these outcomes is likely to be played out over the course of many years. Even if the exchange rate is stable, a small open economy will still take world price as given, for most commodities, poorer countries will find themselves in this position. Important to know just who consumes and produce $s$ the importable and exportable. In many agricultural cases, the poor will comprise both groups. Again, one would expect the impact of globalization to differ across the urban and the rural poor.

Globalization is debatable; "Contemporary globalization has had some important positive consequences with respect to cultural regeneration, communications, decentralization of power, economic efficiency and the range of available product but Neoliberal policies toward globalization have had many negative consequences in regard to increase ecological degradation, persistent

${ }^{17}$ Hazel Handerson as quoted by Ikram Azam, The New Political Economy Paradigm, p. 105106. 
poverty, worsen working conditions, various cultural violence's, widened arbitrary inequalities and deepened democratic deficit", and Jan Art Scholte said that "globalization is not inherently good or bad, his outcome are largely the result of human decision that can be debated and changed"18

Even globalization is debateable, we should always be aware of its negative impact, as depedency of our country become guarantee. Persisten poverty something absolutely should be avoided.

\section{Impacts on Labor Market}

Labor market is The market in which workers find paying work, employers find willing workers, and wage rates are determined. And wage rate determined by intersection of deman and supply of working hours.

Globalization made cheaper price of labor in labor market. As Indonesia is not ready for liberalization itself. Indonesian labor has minimum skill and paid with low price. As spoken by former third president of Indonesia Bacharuddin Jusuf Habibie the balance of working hours must be given attention. And the problem of human resources is key issue in developing and builds Indonesia. One report shows the result that wages and non wages are positively related to industry level and that wages are positively linked to increases in foreign investment, suggesting positive link between globalization and working condition in Indonesia. No wonder thousands of Indonesian's workers fled to abroad expect higher income. Leaving their family for ten years or more, facing harsh attitude from their employer.

Mahatir Muhammad (former of Malaysian Prime Minister) views globalization remains state-centric. "Mahatir sees Globalization as leading to clashes between regions and the power of states. As such, there are ideological overtones embedded in this process. For Mahatir Globalization is a process advocated explicitly by Western financial capitalist and implicitly by U.S. government to promote the expansion of markets and their form of democratic government. This prodemocratic neoliberal or market oriented policies are seen to be advocated by multinational companies and Western dominate international financial institution such as the International Monetary Fund (IMF) and International or Foreign-Funded domestic NGOs to benefit Western state and their financial interests". ${ }^{19}$

\footnotetext{
${ }^{18}$ Jan Art Scholte, Globalization a Critical Introduction, p. 9.

${ }^{19}$ Bridget Welsh, Malaysia and Globalization, in East Asia and Globalization, edited by Samuel
} S. Kim, (USA: Rowman \& Littlefield Publisher Inc., 2009), p. 235. 


\section{Indonesia and Globalization}

Indonesia case, economic growth in 2011 increases by $1.3 \%$, and that is not in line with people welfare. Contrast views could be seen clearly in big and capital city, luxury buildings and houses surrounded by cardboard houses, many modern facilities are untouchable for poor people, and globalization in another side globalization's unpeople, The dichotomy between rich and poor sharpen means economic gap is increasing.

Globalization is driven byone of it is liberalization. Indonesia has gone a long way in liberalizing its economy, but the result is far from perfect, rising poverty and inequality is clearly shown. "If all world trade barrier removed, what will happen is a people with a power will compete and vise virsa, who can not compete will be edged off. Within 25 up to 50 years later, we are not ready yet for liberalization, not because we are so nationalist or protectionist, but only in last 27 years Indonesia has an opportunity to know how economic mechanism is, and develop our human resources, infrastucture, while another state has that opportunity for hundred years and more. If we have to, than for sure we will defeat. Other nations have progress in sciences and technology, capital, experince, and national robustness. Than, we should reconcile with liberalization, otherwise we will be isolated. liberalization is not suitable with indonesian culture." ${ }^{20}$

Liberalization is closely aligned with globalization, and is not suitable for Indonesian culture, it will marginalized lower class society or part of society who could not be able to compete within unfair competetion, Indonesia will be marginalized as well by developed countries.

If only a government focused on the growth of industrialization growth trend which is foucused on city. This will create more disparities of income and development between region. And business power will be strongger and if thi is persistensly happening, just wait for the 'time boom' which will threaten economic growth in future.

In the last decade, equality become the main issue to be concerned. The increase of economic growth in indonesia is infact is increased by the wealthy people of Indonesia. And than the gap between the rich and the poor has increased.

\footnotetext{
${ }^{20}$ Bacharuddin Jusuf Habibi, "Liberalisasi Ekonomi Pemerataan, dan IPTEK", Editor Loekman Sutrisno \& Faraza Umaya, Liberalisasi Ekonomi, Pemerataan dan Kemiskinan, (Yogyakarta: Tiara Wacana, 1995), p. 3.
} 
Government and other stakeholders, however, agree that WTO and it's accompanying institutions regulating world trade are critical to global prosperity and deserve to be strengthened.., Bilateral and regional agreements have diverted the attention of government from global negotiations. At worst, they are establishing a discriminatory "spaghetti bowl" that will long frustrate the creation of truly global markets". ${ }^{21}$

It is true only for upper class people, it only increases the growth of economy in digit. But not the welfare of lower and middle class people. Besides increasing the gap of rich and poor, automatically it increases the rate of poverty as well.

Behind the increasing interconnectedness promised by globalization are global decisions, policies, and practices. These are typically influenced, driven, or formulated by the rich and powerful. These can be leaders of rich countries or other global actors such as multinational corporations, institutions, and influential people. In the face of such enormous external influence, the governments of poor nations and their people are often powerless. As a result, in the global context, a few get wealthy while the majority struggle. ${ }^{22}$

This statement intended that eventough a government have a will to decide a policy which is for the interest of poor people, a goverment eventually powerless. This is the true ficture of politics to day.

\section{Poverty and Globalization}

Poverty phenomena around the world really touching our sensibility, where we see around the children in schooling age should fight with the reality they are facing, war with the time and obsession, for fulfilling their hope and imagination. In fact the children is human capital of the country should be given adequate education, and fair state of health. But the reality shows that many of the children in developing country should become labor in their childhood time. Lack of clean water is killing 5000 children a day in developing country. This News is really pathetic. As most of the poor they have lack accesses to sanitary and watery necessities.

Children in developing nations have limited access to education, economic, social and cultural factors keep some 1021 million children, especially girls,

\footnotetext{
${ }^{21}$ Sumner J. La Croix and Peter A Petri, New Challenges to the Global Trading System, p. 8.

${ }^{22}$ Anup Shah, "Causes of Poverty", http://www.globalissues.org/issue/2/causes-of-poverty, accesed on September 10, 2012
} 
from attending school. Faced with difficult choices, parents often take girls out of school to care for younger siblings, help with household responsibilities, or work outside the home to contribute to family income.

Poverty is the inability to satisfy one's basic needs because one lacks income to buy goods and services. Basic need is, food, sheltter, water, house, education, health, and comfortness etc. Yeah, for some people were not easy to acces those need and the facts shows that poverty around the world gets more terrible day by day.

Report taken from poverty.com says:

Around the world, in rich or poor nations, poverty has always been present. In most nations today, inequality - the gap between the rich and the pooris quite high and often widening. The causes are numerous, including a lack of individual res-ponsibility, bad government policy, exploitation by people and businesses with po-wer and influence, or some combination of these and other factors. ${ }^{23}$

Bad government policy here is a policy which is un pro-poor. In other word obviously, global economy made global poverty. Which means globalization does not reduce or alleviate poverty.

Some 21,000 children die every day around the world. ${ }^{24}$ That is equivalent to: (1) 1 child dying every 4 seconds; (2) 14 children dying every minute; (3) A 2011 Libya conflict-scale death toll every day; (4) A 2010 Haiti earthquake occurring every 10 days; (5) A 2004 Asian Tsunami occurring every 11 days; (6) An Iraq-scale death toll every 19-46 days; (7) Just under 7.6 million children dying every year; (8) Some 92 million children dying between 2000 and 2010.

It seems that human soul is unworthy anymore, where the authority around the world just busy on expanding their power. hunger people around the world is a victim of unfair and unjustice system created by the authority. How come we overcome a poverty when a state only care on buying a weapon than to prosper their own people, olny agree to many world agreement without looking at their people ability, only care on their sovereignity than to their people welfare.

Facts that the rich gets richer, and poor get poorer In Indonesia, could be described by news taken from Forbes magazine (based in New York, America), that forty richest people in Indonesia possessed \$ US 88,6 million compatible with (Rp 850 trillion), and this total income raise $4 \%$ compared to last year. Wo-

\footnotetext{
${ }^{23}$ www.poverty.com, accesed on September 10, 2012.

${ }^{24}$ www.poverty.com, accesed on September 10, 2012.
} 
rthiness of that amount only possessed by forty people, while formal employee including labor, 42,1 million people sharing income amount Rp 1.450 trillion. In this free economics system, no wonder if someone can possess income in fantasist amount. ${ }^{25}$ This facts also describe that globalization increase the gap between the rich and the poor.

\section{Poverty and Global Debt Trap}

From another perspective the cause of poverty in it's context with globalization is "Poverty - is the result of the exceedingly exploitative Global Debt Trap." ${ }^{26}$ When the dollar become the standar exchange, the increase in the value of dollar toward rupiah will increase the amount of the debt. In last decade government expenditure is deficit. The expenditure budget is increasing, and amount of the debt is increasing as well. IMF and World Bank are institutions which are responsible for the debt of developing countries. They give the debt with awareness that it could not be repaid.

Institutions which are responsible for globalization, as political project promoted according to the protestor at G8 summit are; "IMF, World Bank, WTO, G8 (the G7 plus Russia) and the EU dominated by powerful vested interest, the structure of global economic management constitute the core of wider system of liberal governance subordinating the world and its people to the dictates of a liberal ideology and global corporate capitalism". ${ }^{27}$

Caught in the trap of having to repay massive debts, most developing country governments-representing 80 percent of the world's population-have felt they have had little choice but to agree to implement these reforms in exchange for IMF assistance. The results, however, have brought ruin to national economies, cutbacks in schools and hospitals, increased poverty and hunger, and environmental harm. ${ }^{28}$

The IMF came to hold virtual neo-colonial control over developing countries as a result of the Third World "debt crisis" of the 1980s. In the 1970s, commercial banks were eager to make large loans to developing countries and newly independent countries. The interest rates on these loans were initially very low, but variable. But when interest rates were raised sharply in the early 1980 s, hea-

\footnotetext{
${ }^{25}$ Pemerataan, Harta Rp 850 Triliun, Ekonomi, Kompas, Edisi Sabtu, 1 Desember 2012, p. 17

${ }^{26}$ Ikram Azam, International Political Economy: Globalization and Altruistic Ethical Economics, ABC Enterprises, 2012, P. 140

${ }^{27}$ David Held \& Anthony, Globalization/anti-globalization, MPG Books Ltd. Britain, 2007, p. 137

${ }^{28}$ John Cavanagh, Carol Welch, and Simon Retallack, "The IMF Formula: Prescription for Poverty", IFG Bulletin, 2001, Volume 1, Issue 3, International Forum on Globalization, http://www. thirdworldtraveler.com/IMF_WB/IMF_Formula_PrescripPover.html
} 
vily indebted countries suddenly found themselves unable to make soaring interest payments on these bank loans, and many were simultaneously indebted to the World Bank. That's when the IMF stepped in. ${ }^{29}$

\begin{abstract}
The root cause of all the current human evil is in the arena of the exis-ting system of the political economy: the 21st Century New International Imperialism and its cohorts: International Capitalism and Colonialism, collusively cultivating the corrosive Corporate Culture. The IMF, World Bank and their allied institutions and instruments like the WTO, and col-laborators like the MIC, are engineering the whole charade. ${ }^{30}$
\end{abstract}

The facts is that countries which are tied with the international debt, their economy is not going better. But they are trapped into deeper debt. They need to pay the debt which is increases year by year. And than to run their countries they need more loan.

\title{
Debt Trap (Case in Indonesia)
}

It can be concluded that the key causes of the global debt trap are both endogenous and exogenous, i.e.: (i) International Imperialism, Capitalism and Colonialism. (ii) And its Indigenous Counterparts.

No wonder why, developing country, like Indonesia fall deeper in to debt trap. Debt becomes really big disaster, when we are adicted to it. Debt in Indonesia, the data taken from Indonesian Editorial of Metro TV on November 25, 2011: Indonesian's debt is Rp 1.768 Trillion increase Rp 495 Trillion from last decade. Averagely national debt is increasing Rp 49.5 Trillion/year or Rp 13.561.643.800/day. Terrible, where each individual carry debt amount Rp 7,4 Million. And the more terrible thing is that $45 \%$ of our debt is in \$US currency. When there is little incerease on \$US dollar currency, Indonesian foreign debt will increase significantly. If this is going on, our country will come to bankruptcy of economy. Actually the problem of national debt do not only happen in Asian or African coutry, but also happen in Euoropean country like in Greece, Italy, Irlandia, and Portugal. Clearly, debt becomes big problem on economy in many country. If this is the fact, the quistion is how come the poverty will be alleviated, where the state mainly focus on debt matter.

As mentioned one of the key cause of the Global Debt Trap is capitalism. Capitalism is just another form of exploitation. Exploitation of poor people by capitalist. Little example, many law cases in Indonesia, mostly won by who own

\footnotetext{
${ }^{29}$ John Cavanagh, Carol Welch, and Simon Retallack, "The IMF Formula".

${ }^{30}$ John Cavanagh, Carol Welch, and Simon Retallack, "The IMF Formula".
} 
capital. And in international scheme, capitalist state rule upon poor countries. Beside debt rate, Rate of poverty and unemployment keep rising in Indonesia The Center for Welfare Studies reported that" the number of poor people in Indonesia increased by 6.7 percent over the last three years to 43.1 million. The report showed the number of Indonesians living in extreme poverty was 40.36 million in 2008, 44.83 million in 2009, and 43.07 million in 2010." ${ }^{31}$ It means that within three years there is 2.71 Million increase on poverty in Indonesia. According to BPS (statistic centre institution) data the number of poverty is 30.018 Million with 12.49 percent in 2011; even the result is doubted with many other sides. The poverty line used was the monthly per capita earnings of Rp 243,729 (\$26.80)

Even a minister of economic said there is significant increase in economic growth rate. But it touches upper level of people, per capita income increase year by year. But poverty rate also does not decrease significantly. In other way that increase in per capita income only increases the wealth of rich people of Indonesia as mentioned. This fact reveals many families are not benefiting from national economic growth. Fifty percent of Indonesia's population is still poor, living on less than US\$2 per day. While the number of unemployment approximated increase 1.3 million per year. ${ }^{32}$ If this continues, it will create unstable progress in terms of the country's prosperity in the future.

Poverty extends beyond low incomes and the ability to access basic needs. It closely represents a life situation of lower level or poor people in Indonesia. Reducing poverty in Indonesia is not about having limited resources, but it is more about having pro-poor policies and effective institutions, fair distribution, trustee leader. In Indonesia alone, target of poverty is reduced to $9.5-10.5 \%$, it is quite high rate of poverty.

Means economic growth on paper is not everything, but the thing is people's welfare in true sense and in reality. One of the indicators is reducing poverty. Unresolved issue: one-sixth of the world's population lives in extreme poverty. The poorest of the poor tend to be untouched by globalization financial in developing countries is associated with higher consumption volatility. ${ }^{33}$

31 Iin P. Handayani, The writer is a professor at Murray State University, Kentucky, http://www.thejakartapost.com/news/2012/02/13/beyond-statistics-poverty.html, accesed on August $30,2012$.

32 Yudha Manggala P Putra, Pengangguran Indonesia Bertambah 1,3 Juta Orang per Tahun, http://www.republika.co.id/berita/nasional/umum/12/05/01/m3crmx-pengangguran-indonesia-bertambah-13-juta-orang-per-tahun, accesed on August 30, 2012.

${ }^{33}$ Prasad et al quoted by Ann Harrison and Margaret McMillan, p. 195. 
One-sixh of population in the world are living in poverty, no more than onefifth of population are living in prosperity. There is clear imbalance in the welfare of people in the world. When the poor is untouched by globalization, it means year by year there are more and more poor people in the world. And the future of the world will be worse.

Ahsan abdullah in his book "Internet and Pakistan as quoted by Ikram Azam said "Poverty is often blamed on Population Explosion. At best or worst, they are cyclical. But one should never forget the core cause of Poverty: Imperialistic Capitalistic Exploitation. Today its greatest manifestation is the evermounting and mountainous International Debt. There is no hope for Poverty Alleviation without writing off the International Debt-unconditionally-save the sole condition that henceforth no more debts will be given and taken-in the 21 st century. ${ }^{34}$

In the free market the price is determined by market trough demand and supply mechanism. The capitalis has superiority over demand and supply and they determine the market condition. Day by day, year by year, they will be more superior and leave the poor far behind. And it becomes worse with the new form of imperialism. In form of economy and politic imperialism. Which is shaped "imperialistic capitalistic imperialism".

No hope in poverty alleviation in this condition. With all it cases and proble. It can be solved when globalization is run by genuine and truly concept of globalization. For the interest of all countries. And not for the interest of some countries. Poverty alleviation is non-sense without it, Without writing off the international debt conditions, without removing all form and all kind of imperialism.

\section{Islam and Poverty Alleviation}

Islam is a religion of peace, just and equitable. It means submission, surrender, and obidience. Islam Critisize accumulation of capital. And promote equal distribution of income. It has unique concept of poverty. It covers five fundamental aspects. Poverty is Where an individual fails to fulfill any of five basic requirements of life: religion, physical self, intellect or knowledge, offspring, and wealth. It means that needs not only seen from physical fulfilment need aspect.

Principally, all the people in the world will live in prosperous way when there is equal distribution of income among people. It happens in history where

${ }^{34}$ Ahsan Abdullah quoted by Ikram Azam, The New Political Economy Paradigm, PFI, 2002, p. 152. 
no people found to be poor. As all are living in welfare. This is happen trough equal redistribution of income mechanism. It also means that creating equal opportunities for accumulating income is obligatory.

Islamic economic system has its own system in alleviating poverty Trough zakat and waqf. Zakat itself become the characteristic of Islamic economic system And instrument of redistribution of income from the rich to the poor. Zakat means purifying. It purifies the wealth of a muslim. And zakat is cumpulsory for all muslim and as one of the five pillars. It can be used on eight purposes. Among them are the poor, the needy, the debtor, the slaves, and the travelers in need, administrative of zakat, those whose hearth are made inclined (to Islam), and in the way of Allah. And waqf is voluntary giving, it means hold, confinement. Waqf is pepetual charity that means holding certain property and preserving it. Whre the reward for the one who give waqf is not interrupted.

Potential amount of zakat and waqf is so fantastis. In Indonesia it amount up to trillions rupiah. Even not alleviating poverty it can help reducing poverty. Unfortunately awareness in paying zakat is very low for almost all muslim countries. And no wonder why poverty is become continous problem. Poverty in principle is the responsibility of the state. Even it is mentioned in constitutional law. "the destitutes and the poor are protected by a state. But in facts, they are not in safeguarding of a state.

Overall accumulation of capital prevented income to be distributed equally. While Islamic's tenets that everyone should be given equal opportunity in accumulating capital to obtain fair and just income.

\section{Closing Remark}

It can be concluded that the meaning of globalization has the same meaning with internationalization, increasing integration and interdependence among nation, liberalization, and thr global power rule over low power country. Globalization itself speeded up by the help of technology, deregulation, and media. It also easyly understood by free trade as it has the same characteristic with globalization. Globalization indeed inescapable. It could create global prosperity depend on the policy maker of this world. Unfortunately, institution which is responsible for this influences the political world partially and applied "double standard", in case favorable for some countries and harms other countries. The facts shows loan of developing countries since 1972, total external many developing countries averagely keep increasing. That foreign aid is trapping not helping. It shows globalization perpetuates the inequity and exploitation innate in capitalism: globalization polarizes the globe and therefore creates a smooth 
more unfair world. Indonesia must develop new pattern of policy and regulation, and all policy makers should rethink and reshape their view toward globalization, where state, market, and civil society can work hand in hand in dealing with economic issue. Unfortunately, the fact is that the government has not paid adequate attention to the need to shape the regulatory framework to a form appropriate to globalization. And in global context, in globalization global poverty happen and far beyond the expected one as many studies found that increasing in globalization is associated with increasing inequality. World economic system should pro-poor people and poor nations, and how to include social and redistribution justice in the economy to deal with the dangerous loss of safety and social cohesion that goes hand in hand with greater economic instability born by neo-globalization and market regulation, in order harmony living exists on this earth. []

\section{Bibliography}

Amhar, Fahmi, "Politik Global, Penjajahan Ekonomi Indonesia, Implikasi dan strategi Menghadapinya", Muhaimin Iqbal, "Penjajahan IMF di Indonesia dan Upaya Solusinya", Jurnal Kajian Islam Imperialisme, Lembaga Kajian dan Pengembangan al-Ihsan, Depok, No. 1, Vol. 3, 2008.

Azam, Ikram, International Political Economy: Globalization and Altruistic Ethical Economics, ABC Enterprises, 2012.

, The New Political Economy Paradigm, Islamabad: Pakistan Futuristics Foundation \& Institute, 2003.

Bhagwati, Jagdis, In defense of Globalization, New York: Oxford University Press,, 2004.

Cavanagh, John, Carol Welch, and Simon Retallack, "The IMF Formula: Prescription for Poverty", IFG Bulletin, 2001, Volume 1, Issue 3, International Forum on Globalization, http://www.thirdworldtraveler.com/ IMF_WB/IMF_Formula_PrescripPover.html

Croix, Sumner J. La and Petri, Peter A, New Challenges to the Global Trading System, in Challenges to the Global Trading System: Adjustment to Globalization in the Asia-Pacific Region, New York: Routledge, 2007.

Davies, Gloria \& Nyland, Chris (Editor), Asian Region: Impacts and Consequences, UK: Edward Elgar Publishing Limited, 2004.

Dinopoulus, Elias, and Friends, Trade, Globalization, and Poverty, Taylor and Francis e-library, 2007

Gallagher, Vincent A., The True Cost of Low Prices: The Violence of Globalization, Michigan: Orbis Book, 2010. 
Habibie, B.J. and Friends, Liberalisasi Ekonomi, Pemerataan dan Kemiskinan, Yogyakarta: PT. Tiara Wacana, 1995.

Handayani, Iin P., " The writer is a professor at Murray State University, Kentucky”, http://www.thejakartapost.com/news/2012/02/13/beyond-statisticspoverty.html.

Harian Kompas, Pemerataan, harta Rp 850 triliun, Ekonomi, Edisi Sabtu, 1 Desember 2012.

Held, David \& Anthony, Globalization/Anti-Globalization, MPG Books Ltd. Britain, 2007.

http://www.bi.go.id/weben/PublikasiKebijakan/MoneterOutlook/Ekonomi/Indone siaeconomic/outlook/2008/html

Indonesian Economic Outlook 2008-2012, ASEAN Economic Integration and the National Economic Outlook, Economic Research Bureau Directorate of Economic Research and Monetary Policy,

Kabul, Ravi and friends, Equity and Growth in a Globalizing World, Washington DC: Commission on Growth and Development, 2010.

Kim, Samuel S. (Editor), East Asia and Globalization, USA: Rowman \& Littlefield Publisher Inc., 2009.

Limbong, Bernhard, Stop Making Money, Jakarta: Margareta Pustaka, 2012.

Majalah Tempo, Edisi 24-30 Desember 2012.

Manning, Chrish and Sumarto, Sudarno (Editor), Employment, Living Standards, and Poverty in Contemporary Indonesia, Singapore: ISEAS Publishing.

Muh. Abdullah, Teori Ekonomika, Tangerang: Jelajah Nusa, 2012.

Oriscoll, William \& Clark, Julie (editor), Globalization and the Poor; Exploitation or Equalizer?, USA: International Debate Education Assosiation, 2003.

Perkins, John, Confession of an Economic Hit Man, San Fransisco: Berret Koehler Publisher, 2004.

Pilger, Jon Pilger, "Globalisation in Indonesia Spoil of a Massacre, Guardian Weekend, 14 July 2001. http://www.inminds.com/globalisation-in-indonesia/html/30082012, accesed on Auguts 30, 2012.

Pizzuti, Felice Roberto, Introduction Market and Institutions in Neo-Globalization, in Globalization, Institutions and Social Cohesion, edited by Maurizio Franzini \& Felice R Pizzuti, Germany: Heidelberg, 2001.

Putra, Yudha Manggala P, "Pengangguran Indonesia Bertambah 1,3 Juta Orang per Tahun", http://www.republika.co.id/berita/nasional/umum/12/05/01/ m3crmx-pengangguran-indonesia-bertambah-13-juta-orang-per-tahun, accesed on August 30, 2012 
Revallion, Martin, "The Debate on Globalization, Poverty, and Inequality: Why Measurement Matters", The world Bank Development Research Group, Poverty Team, 2003.

Robertson, Raymond, and Friends, Globalization, Wages, and the Quality of Jobs (Five Countries Studies), Washington DC: The World Bank, 2009.

Rodrik, Dani, Has Globaliation Gone Too Far, Washington DC: Institute for International Economics, 1997.

Scholte, Jan Art, Globalization a critical Introduction, New York: St. Martin's Press, Inc, 2000.

Shah, Anup, "Causes of Poverty", http://www.globalissues.org/issue/2/causes-ofpoverty, accesed on September 10, 2012.

Soesatro, Hadi, "Globalization: Challenges for Indonesia", Economic Refrorm Today (Director of the Centre for Strategis and International Studies (CSIS), and a member of the National Economic Council in Indonesia) http://www.cipe.org/sites/default/filespublication-docse35_10/pdf/30082012 accesed on August 30, 2012.

Tanjung, Hendri and Zaman, Asad, "Between Free Trade and Protectionism", Published in The Jakarta Post, 3rd may 2010, http://thejakartapost.com/ news/2010/05/03/between-free-trade-and-protectionism.html

Taylor, Jean Gelman, Global Indonesia, USA: Routledge, 2012.

The Jakarta Post, Economic Outlook 2013, December 2012 edition. 